\title{
Determinant Analysis of Education Inequalities in Indonesia
}

\author{
Evi Syuriani Harahap ${ }^{1}$, Indra Maipita ${ }^{2}$, M. Fitri Rahmadana ${ }^{2}$ \\ ${ }^{1}$ Master Student in State University of Medan (Unimed), Medan, Indonesia \\ ${ }^{2}$ Lecturer in State University of Medan (Unimed), Medan, Indonesia \\ eviharahap21@gmail.com
}

\section{Abstract:}

Education is the main capital for humans to prosper. The importance of the role of education in improving welfare requires the need for equal distribution of education in each region regardless of socioeconomic, gender and racial backgrounds. In making educational equality, it is important to know the factors that influence educational inequality, namely income inequality, poverty and education gap. Reducing the income inequality, poverty and education gender gap in each province in Indonesia will reduce education inequality which is the responsibility of all parties, both the central and regional governments. The purpose of this study is to analyze the effect of income inequality, poverty and education gender gap on education inequality in Indonesia in 2016-2018. Data analysis was performed using the Ordinary Least Square $(O L S)$ method with a panel data regression estimation model using the help of eviews 9.0. Estimation results show that partially income inequality, poverty and gender gap in education have a positive and significant effect on educational inequality in Indonesia, while simultaneously income inequality, poverty and education gender gap negatively affect education inequality in Indonesia.

Keywords

inequalityineducation, inequality of income; poverty, gendergapineducation

\section{Introduction}

Education is one of the efforts to improve the ability of human intelligence, thus he is able to improve the quality of his life. So, to create the highest quality of human resources, education is becoming an important factor to be considered. The importance of education is also reflected at MPR No. II/MPR/1993 which states that the national education aims to improve the quality of Indonesia people that is religious people, and pious to God Almighty, noble character, has high personality, discipline, work hard, responsible, independent, smart, healthy, physically and mentally healthy. (Sugiharto, 2020)

Inequality of income can affect the level of education (Kaplan et al, 1996 and Sylwester, 2000). Large income inequality tends to spend a smaller budget on education so that the quality of education becomes less good. One reason why regions with a high level of inequality spend a small budget on education is in areas with increasing disparities, there are differences in priorities between the rich and the majority of other citizens (Kaplan et al, 1996). The following data income inequality in Indonesia in 2016-2018.

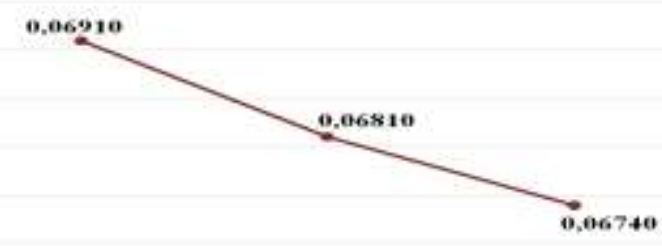

$2016 \quad 2017 \quad 2018$

Figure 1. Inequality of Income among Regions in Indonesia

Source: Statistics Indonesia, 2019 
The figure above shows that income inequality between regions in Indonesia as measured by the Williamson Index over the past 3 years has decreased every year, although the decline is not too large. This decline in the Gini index indicates that the distribution of income received by the community between regions in Indonesia is increasingly even.

Previous research on the effects of income inequality and educational inequality has been carried out by Ariutama and Syahrul (2014) and Sylwester (2000). The results of the study stated that income inequality causes educational inequality, so it can be concluded that the opportunity for people to access education is getting smaller

Poverty is also one of the factors that affect educational inequality. Poverty has a considerable impact on the demand for school and enroll in school, so that the level of educational attainment for the poor will be low. Children from poor households will tend to postpone going to school and tend to increase dropout rates which will slow the attainment of educational levels which are a consequence of poor households (Shapiro et al, 2001). The following data is poverty in Indonesia in 2016-2018.

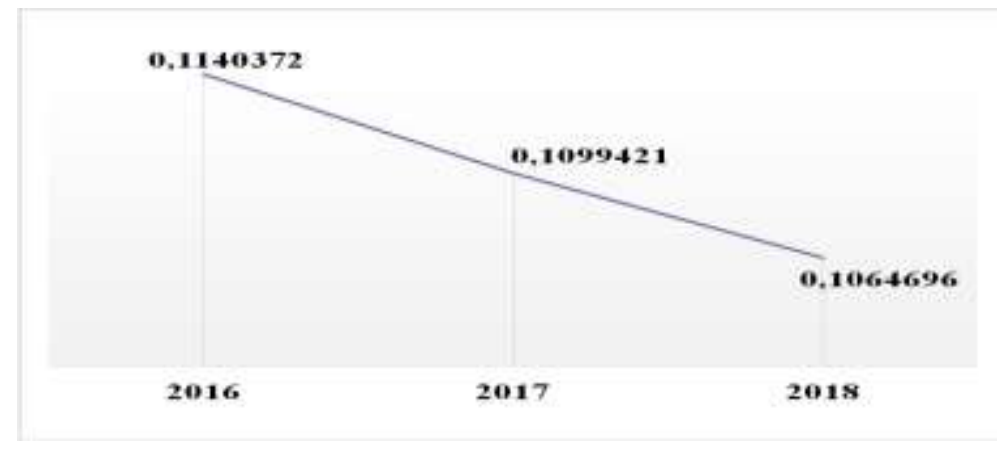

Figure 2. Poverty in Indonesia

Source: Statistics Indonesia, 2019

The graph above shows that the number of poor people from 2016-2018 has decreased every year. The decline in the poverty rate means the number of people below the poverty line shrink every year.

Several previous empirical studies related to the effects of poverty on education shows that poverty affects the education. The results of his research indicate that the level of household welfare is a significant determinant for children to go to school. Due to economic factors, poor families, parents have become more expect their children to help the family economy so that the number of high school dropouts has implications for the increase in inequality of education (Shapiro et al, 2001; Suryadarma et al, 2006; Grim, 2011; Psachoropoulos and Arriagada, 2016) .

Inequality in education can also be seen from aspects of gender equality that occur in an area. Suryadi and Idris (2010) say the education sector is the most decisive sector in the effort to realize gender equality which will open up opportunities and opportunities in various fields. Gender equality can benefit men and women in terms of education, employment and services (Nugroho, 2011).

Gender gap can be demonstrated on the ratio of the number of males were literate with a population of women. Here are the data comparing the literacy rate of men and women in Indonesia in 2016-2018. 


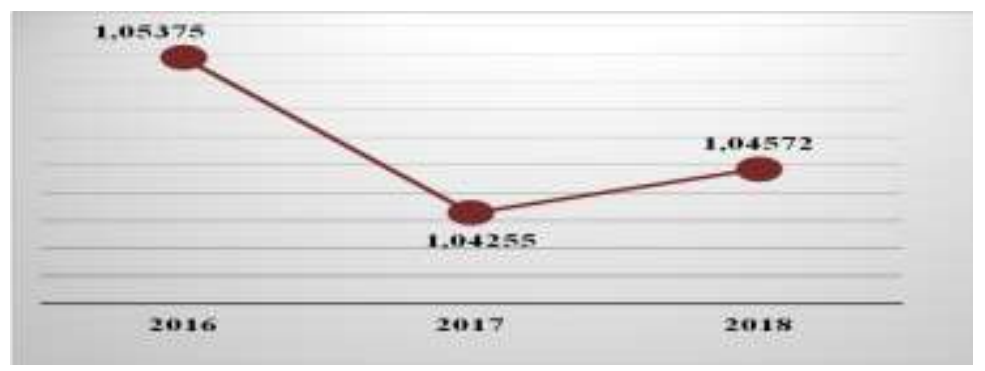

Figure 3. Gender Gap Education in Indonesia

From the graph above it can be seen that the ratio of literacy rates between men and women (gender gap education) in 2016-2018 has fluctuated. In 2017 there was a decrease in the gap between male and female literacy rates. This means a decrease in illiteracy rates among women. Whereas in 2018 there was an increase in literacy rates between men and women. This means that there is an increase in female illiteracy which means that the gender gap in education between men and women increases.

Digdowiseiso (2010) and Bustomi (2012) state that the large difference in literacy rates between genders has a positive and significant effect on the height of the gini index. The wider the gender gap, the higher the level of educational inequality. Other research that examines gender inequality with education is (Thomas, 2001) which shows that gender gap is positively related to educational inequality. Reducing the gender gap in the education sector is needed to overcome the imbalance of education in 85 research countries. Every effort to reduce educational inequality must aim to narrow the gender gap (Senadza, 2012).

From these problems, education in Indonesia has not been evenly distributed, especially in every region in Indonesia. This can be seen from the decline in community participation in basic education and the implementation of 9-year compulsory education as seen from the average length of school. So it is important to know what factors influence education inequality in each of the regions in Indonesia as measured by the Gini index of education. Therefore, this study will measure education inequality through the 2016-2018 education gini coefficient for 34 provinces in Indonesia. So the title of this research is "Analysis of Determinants of Educational Inequality in Indonesia".

\section{Literature Review}

\subsection{Concept of Educational Inequality}

According to Yagami (2013) educational inequality is a mismatch between what should be or what is expected with what is happening. This means that the development of education must be equitable without any difference, so that the people or the community can enjoy a decent and quality education.

Inequality in education becomes very important in knowing the effectiveness of the education system and as a measurement tool to evaluate the educational process. Some reasons why educational inequality is something that needs to be investigated because of the link between welfare and efficiency. In terms of welfare, quality education is able to improve the ability of individuals to strengthen their welfare directly. Although there are still education gaps between the rich and the poor. If poverty conditions are considered "deprivation from meeting the minimum educational needs of primary schools", then welfare inequality must include measures of educational inequality (Sen, 2000).

According to Tesfeye (2002) there are 4 factors that affect educational inequality, namely 1 . Characteristics of the family consisting of income, level of welfare, family size, level of education of parents, 2. Characteristics of children or students consisting of levels of 
student ability, health, nutrition, cognitive power, and gender, 3. Quality of education including teaching quality, student and teacher ratio, class size, teacher qualifications, quality of classrooms and learning equipment, curriculum, school infrastructure and routine maintenance, electricity supply, drinking water and toilet facilities , 4. The rate of return from education.

Meanwhile according to Digdowiseiso (2010), educational inequality in Indonesia can be measured from 4 education indicators namely; School participation rates, 2. Pure participation rates, 3. Educational attainment, namely the number of students completing several levels of education, 4. Literacy rate, the individual ability of students to read and write.

According to BPS (2019) indicators of educational attainment can be seen from the average length of schooling and school participation rates. However, increasing these achievements does not necessarily imply equitable education. Thomas et al (2001) state that education indicators are less effective in describing educational inequality. Therefore it is necessary to measure other educational inequality such as the Gini index of education.

\subsection{Poverty and Inequality in Education}

Someone can be said to be poor or live below the poverty line if income or access to goods and services is relatively low. In absolute terms a person is declared poor if his income level or standard of living is absolutely below the poverty line. In general poverty is the inability of a person to meet the standard needs of every aspect of life. According to Sen (2000) poverty is more related to the inability to reach the standard of living than whether the standard of living is achieved or not.

To measure poverty, there are several measurement methods, for example: BPS uses the concept of ability to meet basic needs (basic needs approach). With this approach, poverty is seen as an inability on the economic side to meet basic food and non-food needs as measured by expenditure. So the Poor Population is the population that has an average monthly per capita expenditure under the poverty line (BPS, 2019). Other measurement tools are the World Bank Criteria using a measure of income of less than $\$ 2$ dollars per day and the Asian Development Bank (ADB) uses the poverty indicator used by the government namely Purchasing Power Parity.

Todaro (2011) divides poverty based on its causes into natural and structural poverty. Natural poverty occurs due to failure of an individual and / or physical environment as the object so that a person becomes difficult in doing business or getting work. Structural poverty sees poverty as a relative part, where there is a group of people who are poor while other groups are not poor. While poverty based on severity is divided into absolute poverty and relative poverty.

Some previous empirical studies related to the effect of poverty on education show that poverty influences education. The results of his research indicate that the level of household welfare is a significant determinant for children to go to school. Because of the economic factors of poor families, parents are more expecting their children to help the family economy so that high school dropout rates have implications for increasing educational inequality (Shapiro et al, 2001; Suryadarma et al, 2006). This is also supported by research by Grimm (2011) and Psacharopoulos and Arriagada (2016) which states that relatively fewer children from poor families are enrolled in school compared to relatively wealthy households. Children from poor families in particular lack the opportunity to enjoy school and tend to lack school progress. Poor parents prefer their children to work to help parents in their efforts to make ends meet compared to choosing to enroll in school. As a result, educational disparities among community groups will be even greater. 


\subsection{Gender Gap Education and Education Inequality}

Gender gap shows the gap between women and men in getting the benefits of education, employment and services (Nugroho, 2011). Very large gender gap in education (gender education gap) occurs in less developed countries in Africa, with the level of female literacy is less than half the level of male literacy in countries such as Niger, Mali, Guinea and Benin (Todaro, 2011). Gender gaps in education still occur frequently. This is seen from the unfortunate fate that usually befall girls from weak economic families, where they are often faced with a very difficult choice, especially when influenced by perceptions of gender that are still wrong (Suryadi and Idris, 2010).

According to Chernihovsky (1985) School participation rates for boys are higher than girls. In high-income families the education gap between men and women is only small or can be ignored. However, for poor families this difference is too high or even children do not attend school. Boys have a higher tendency than girls to register and attend school especially at the primary level. In the end, boys have a higher education than girls.

Reducing the gender gap in the education sector is needed to overcome the imbalance of education. The difference in literacy rates between genders has a significant and positive effect on the high Gini index. The wider the gender gap, the higher the level of educational inequality. (Digdowiseiso, 2010; Bustomi, 2012; Senadza, 2012 and Sholikhah, et al 2014).

\section{Research Methods}

This study analyzes the factors that influence education inequality in Indonesia from 2016-2018. Factors thought to influence Education Inequality are Inequality Income, Poverty and Gender Education Gap. The type of data analyzed in this study is quantitative data, namely secondary data obtained from various related agencies such as the Central Statistics Agency, the Ministry of Education and Culture and the Ministry of Research in Technology and Higher Education. The data used in this study is panel data which is a combination of annual data (time series) from 2016-2018 and cross sections of 34 provinces in Indonesia. The analytical method used to answer the research objectives consisted of descriptive analysis, Gini analysis of education, and panel data regression analysis. Descriptive analysis illustrates the conditions and educational disparities that occur at the provincial level in Indonesia. The method used to calculate educational inequality is to use the Gini Education Index equation developed by Thomas et al (2001). Systematically the calculation of inequality between regions is calculated using the Williamson Index. According to Hamzah, et al. (2017) to calculate the gender gap in education seen from the male literacy rate and the female literacy rate. Assumption tests are carried out to meet the requirements of a model that will be used. In the panel data model the classical assumption test is used in the form of normality test, multicollinearity test, heteroscedasticity test, autocorrelation test. Panel Data Regression Method will provide the results of the estimation that is Best Linear Unlimited Estimation (BLUE) if all of the Gauss Markov assumptions are met including noncorrelational. Statistical hypothesis testing can be measured from the statistical value of $\mathrm{t}$, the statistical value of $\mathrm{F}$ and the coefficient of determination (Kuncoro, 2013). 


\section{Discussion}

\subsection{Analysis Results}

This section will describe empirical facts related to the development of each research variable, namely educational inequality, income inequality, poverty and gender gap education. The aim is to provide a general description of the object being studied and to find specific things, especially those related to the development of educational inequality in Indonesia.

\section{a. Development of Educational Inequality in Indonesia}

To measure education inequality in Indonesia the Gini index of education is used. Based on the results of the calculation of the education gini index, Indonesia is included in the category of moderate education inequality during the period 2016 - 2018. During this period Indonesian education gini showed an increasing trend over the past 3 years. This increase also occurred in almost every province in Indonesia. The results of calculating the Gini index of education in Indonesia can be seen in the following table

Table 1. Education Gini Index Calculation Results by Province in Indonesia 2016 - 2018

\begin{tabular}{|l|c|c|c|}
\hline \multirow{2}{*}{ Province } & \multicolumn{3}{|c|}{ Index Education } \\
\cline { 2 - 4 } & $\mathbf{2 0 1 6}$ & $\mathbf{2 0 1 7}$ & $\mathbf{2 0 1 8}$ \\
\hline Papua & 0,652214 & 0,615142 & 0,633296 \\
\hline Papua Barat & 0,315360 & 0,363857 & 0,488342 \\
\hline DI Yogyakarta & 0,468048 & 0,471129 & 0,486239 \\
\hline Kepulauan Riau & 0,443039 & 0,455128 & 0,461751 \\
\hline Maluku & 0,395374 & 0,423564 & 0,448644 \\
\hline Jawa Tengah & 0,354085 & 0,376425 & 0,430222 \\
\hline DKI Jakarta & 0,399354 & 0,403219 & 0,410102 \\
\hline Sulawesi Utara & 0,368060 & 0,384993 & 0,407028 \\
\hline Aceh & 0,380784 & 0,394072 & 0,402702 \\
\hline Sulawesi Barat & 0,361261 & 0,370965 & 0,399697 \\
\hline Kalimantan Selatan & 0,364547 & 0,381017 & 0,398353 \\
\hline Sulawesi Selatan & 0,364547 & 0,381017 & 0,398353 \\
\hline Sumatera Barat & 0,330621 & 0,365781 & 0,395035 \\
\hline Sulawesi Tenggara & 0,377969 & 0,374958 & 0,387351 \\
\hline Riau & 0,280402 & 0,309625 & 0,384104 \\
\hline Sumatera Utara & 0,323823 & 0,352392 & 0,379122 \\
\hline Nusa Tenggara Barat & 0,347133 & 0,359231 & 0,374368 \\
\hline Lampung & 0,339371 & 0,358550 & 0,371805 \\
\hline Gorontalo & 0,288621 & 0,321788 & 0,366918 \\
\hline Jawa Timur & 0,324773 & 0,349428 & 0,364857 \\
\hline Kalimantan Barat & 0,312384 & 0,350555 & 0,362553 \\
\hline Nusa Tenggara Timur & 0,292611 & 0,330400 & 0,360685 \\
\hline Sulawesi Tengah & 0,299260 & 0,340214 & 0,359078 \\
\hline Banten & 0,289688 & 0,322934 & 0,357928 \\
\hline Bali & 0,283792 & 0,318447 & 0,352370 \\
\hline Bengkulu & 0,278001 & 0,318253 & 0,351181 \\
\hline Jambi & 0,302288 & 0,336872 & 0,350640 \\
\hline Sumatera Selatan & 0,317437 & 0,335411 & 0,345110 \\
\hline
\end{tabular}




\begin{tabular}{|l|c|c|c|}
\hline \multirow{2}{*}{ Province } & \multicolumn{3}{c|}{ Index Education } \\
\cline { 2 - 4 } & $\mathbf{2 0 1 6}$ & $\mathbf{2 0 1 7}$ & $\mathbf{2 0 1 8}$ \\
\hline Jawa Barat & 0,281854 & 0,292042 & 0,328023 \\
\hline Kalimantan Tengah & 0,265917 & 0,289011 & 0,320830 \\
\hline Maluku Utara & 0,321615 & 0,313826 & 0,320076 \\
\hline Kalimantan Timur & 0,306729 & 0,308771 & 0,309664 \\
\hline Kalimantan Utara & 0,334920 & 0,333682 & 0,296513 \\
\hline Kepulauan Bangka Belitung & 0,294028 & 0,339214 & 0,295609 \\
\hline Indonesia & $\mathbf{0 , 3 0 8 2 7 4}$ & $\mathbf{0 , 3 2 3 7 4 0}$ & $\mathbf{0 , 3 4 0 9 6 6}$ \\
\hline
\end{tabular}

Source: Data processed (2019)

Based on the table above it is known that in 2018 the five provinces that have the highest educational inequality out of 34 provinces in Indonesia are the provinces of Papua, West Papua, DI Yogyakarta, Riau Islands and Maluku. Papua Province's provincial education Gini index in 2018 is 0.633296 and is included in the category of higher education inequality. Whereas the four other provinces, namely DI Yogyakarta, Riau Islands and Maluku, are included in the lack of moderate education.

\section{b. Development of Income Inequality between Provinces in Indonesia}

To measure income inequality between provinces in Indonesia the Williamson Index is used. The results of the Williamson index calculation show that the top five provinces that have the highest income inequality are the provinces of DKI Jakarta, East Kalimantan, West Java, Central Java and Riau for 2018. DKI Jakarta Province has an income gini index of 0.58822 with a high income inequality category. While the other four provinces, namely: East Kalimantan, West Java, Central Java and Riau are included in the category of low income inequality.

\section{c. Poverty Development in Indonesia}

To measure poverty in Indonesia, the ratio of poor people to population in Indonesia is used. Based on the calculation of the ratio of the poor population during the period 2016 2018 Indonesia experienced a downward trend. The results of the calculation of the ratio of poor population by province in Indonesia there are five provinces with the highest ratio of poor population in 2018 are the provinces of Papua, West Papua, East Nusa Tenggara, Maluku and Gorontalo. Although these five provinces are included in the category of the five largest highest poverty in Indonesia, but every year there is a decrease in poverty in each region.

\section{d. Development of Gender Gap Education in Indonesia}

To measure Gender Gap Education in Indonesia, the ratio of male literacy to female literacy is used. Based on the results of the calculation of the gender gap in education in Indonesia from 2016 to 2018, Indonesia experienced a downward trend. This means an increase in the literacy rate of women in Indonesia. The results of the calculation of the ratio of male literacy rates to the rates of female literacy by provinces in Indonesia using the calculation of the ratio of education gender gap, there are five provinces with the highest education gap ratio of 34 provinces in Indonesia in 2018 is the province of Papua, West Nusa Tenggara, Bali, East Java and West Kalimantan. In addition, there was a decrease in the gender gap in education for the four provinces, namely Papua, Bali, East Java and West 
Kalimantan from 2016 to 2018. While the province of West Nusa Tenggara increased the gender gap in education from 2016 by 1.117837 to 1.124071 for 2018 .

\subsection{Testing Requirements Analysis}

After the assumption testing process, the classical assumption test results are obtained as follows: The normality test is used to test whether in the regression model, the independent variables and the dependent variables are normally distributed or not. This test was carried out with Jarque Bera. The assumption of normality can be fulfilled if

Jarque - Bera statistical probability values> 0.05 (Gujarati: 2004). Jarque - Bera statistical probability value of $0.459815>0.05$. Then it can be concluded that the data is normally distributed; Multicollinearity test in this study was conducted by looking at the correlation coefficient between independent variables. If the value of the correlation coefficient between independent variables is above 0.85 then it is suspected that there is multicollinearity in the model. Conversely, if the correlation coefficient is relatively low then the model does not contain multicollinearity (Gujarati: 2004). All independent variables have correlation coefficient values below 0.8 . Then it can be concluded that the model is free from multicollinearity problems; Heterokedastisitas test in this study using the Glesjer Test. If the Prov value $>0.05$, it can be concluded that the model formed in the regression equation does not contain heteroscedasticity problems (Gujarati: 2004). Probability values for all independent variables $>0.05$. This means that the model in the data regression equation is free from heterokedasticity assumptions; Autocorrelation test in this study was seen through the value of Durbin Watson (DW). The way to see the presence / absence of autocorrelation is done by comparing the statistical DW values with DW tables (Gujarati: 2004). The DurbinWatson test results were 1.83204 . Whereas $\mathrm{dL}=1.6174$ and $\mathrm{dU}=1.7383$. because the value of $\mathrm{dU}<\mathrm{dW}<4-\mathrm{dU}$, it can be concluded that there is no autocorrelation disturbance.

\subsection{Results of Data Analysis Techniques}

\section{a. Model Selection in Data Processing}

\section{Chow Test}

The Chow Test aims to determine whether it is better to use a fixed effect model or common effect model. If the Chi-Square probability results $<0.05$, the good model used is the fixed effect model. Whereas if the Chi-Square probability results> 0.05 then a good model is used is the common effect model. It is known that the ChiSquare probability is 0.0000 . Then the Fixed Effect Model (FEM) is a model that should be used.

\section{Hausman Test}

The Hausman test aims to determine whether it is better to use a random Effect model or a fixed effect model. If the Chi-Square probability results $<0.05$, the good model used is the fixed effect model. Whereas if the Chi-Square probability results> 0.05 then a good model is used is the random effect model. The chi-square probability results of $0.0006<0.05$. Then it can be concluded that the model that should be used is the fixed effect model.

\section{b. Estimation Results of Panel Data Regression with the Fixed Effect Model Method}

Based on the results of the Chow and Hausman test, it can be concluded that the right model used in estimating research data is the Fixed Effect Model. The Fixed Effect Model assumes that differences between individuals (cross sections) can be accommodated from differences in their intercepts. So, in each province will have a different intersept which indicates that each region is different from other regions. Following are the results of the Fixed Effect Model research model test 
Table 2. Result test Fixed Effect Model

Dependent Variable: Y?

Method: Pooled Least Squares

Date: 01/04/20 Time: 14:51

Sample: 20162018

Included observations: 3

Cross-sections included: 34

Total pool (balanced) observations: 102

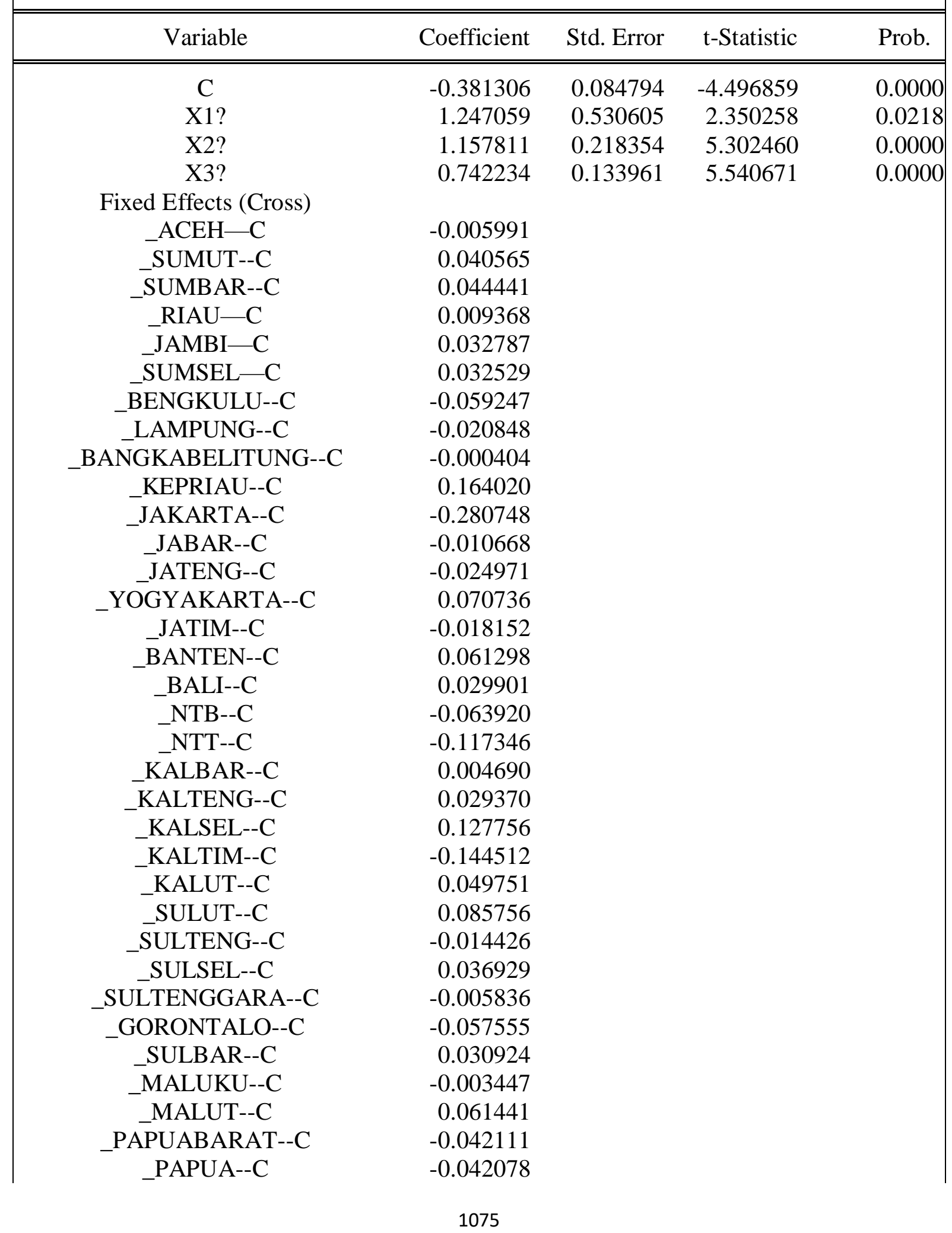




\begin{tabular}{|lllr|}
\hline \hline \multicolumn{4}{l|}{ Effects Specification } \\
\hline \hline Cross-section fixed (dummy variables) & & & \\
\hline \hline R-squared & 0.956396 & Mean dependent var & 0.309340 \\
Adjusted R-squared & 0.932246 & S.D. dependent var & 0.047754 \\
S.E. of regression & 0.012430 & Akaike info criterion & -5.662487 \\
Sum squared resid & 0.010043 & Schwarz criterion & -4.710291 \\
Log likelihood & 325.7868 & Hannan-Quinn criter. & -5.276910 \\
F-statistic & 39.60269 & Durbin-Watson stat & 1.832040 \\
Prob(F-statistic) & 0.000000 & & \\
\hline \hline
\end{tabular}

Source: Eviews 9

Interpretation of the Inequality, Income, Poverty and Gender Education Gap variables by provinces in Indonesia from the table above can be seen in the order of the results of the following data processing:

\section{Indonesian interpretation}

The equality regression model of education in Indonesia is as follows:

From the above equation it is known that:

a. If the Income, Poverty and Gender Gap in Education Gap is zero, then education inequality in Indonesia will decrease by 0.381306 .

b. If the Income Inequality variable rises by $1 \%$ while the other variables namely Poverty and Gender Gap Education remain, then the Inequality Education will increase by 1.247059. The interpretation for the income inequality variable will be the same in every province in Indonesia. This is because the slope (regression coefficient) variable income inequality has the same value in the fixed effect model.

c. If the Poverty variable rises by $1 \%$ while the other variables namely Income Inequality and Gender Gap Education remain, then Education Inequality will increase by 1.157811. The interpretation for the poverty variable will be the same in every province in Indonesia. This is because the slope (regression coefficient) variable income inequality has the same value in the fixed effect model.

If the Gender Gap Education variable increases by $1 \%$ while the other variables, namely Inequality Income and Poverty remain, then Education Inequality will increase by 0.742234. The interpretation for the education gender gap variable will be the same in every province in Indonesia. This is because the slope (regression coefficient) variable income inequality has the same value in the fixed effect model.

2. Interpretation of the Province of Aceh:

$\left(\mathrm{Y} \_\mathrm{ACEH}\right)=(-0.005991-0.381306)+1.247059\left(\mathrm{X} 1 \_\mathrm{ACEH}\right)+1.157811\left(\mathrm{X} 2 \_\mathrm{ACEH}\right)$ $+0.742234\left(\mathrm{X3} \_\right.$ACEH $)$

$\left.\mathrm{Y} \_\mathrm{ACEH}\right)=-\mathbf{0 . 3 8 7 2 9 7}+1.247059\left(\mathrm{X} 1 \_\mathrm{ACEH}\right)+1.157811\left(\mathrm{X} 2 \_\mathrm{ACEH}\right)+\mathbf{0 . 7 4 2 2 3 4}$ (X3_ACEH)

From the above equation it is known that: If the Income, Poverty and Gender Gap in Education Gap is zero then the educational inequality in Aceh province will decrease by 0.387297 .

3. Interpretation of the Province of North Sumatra

If the Income, Poverty and Gender Gap in Education Gap is zero then the Education Inequality in North Sumatra province will decrease by 0.340741 . 
4. Interpretation of the Province of West Sumatra

If the Income, Poverty and Gender Gap in Education Gap is zero then the Education Inequality in West Sumatra province will decrease by 0.336619 .

5. Interpretation of Riau Province

If the Income, Poverty and Gender Gap in Education Gap is zero then the Education Inequality in Riau province will decrease by 0.371938 .

6. Interpretation of Jambi Province

If the Income, Poverty and Gender Gap in Education Gap is zero then the Education Inequality in Jambi province will decrease by 0.348519 .

7. Interpretation of the Province of South Sumatra

If the Income, Poverty and Gender Gap in Education Gap is zero then the Education Inequality in South Sumatra province will decrease by 0.348777 .

8. Interpretation of Bengkulu Province

If the Income, Poverty and Gender Gap in Education Gap is zero then the Education Inequality in Bengkulu province will decrease by 0.440553 .

9. Interpretation of Lampung Province

If the Income, Poverty and Gender Gap in Education Gap is zero then the Education Inequality in Lampung province will decrease by 0.402154 .

10. Interpretation of the Province of Bangka Belitung

If the Income, Poverty and Gender Gap in Education Gap is zero then the Education Inequality in the Bangka Belitung province will decrease by 0.38171 .

11. Interpretation of the Riau Islands Province

If the Inequality of Income, Poverty and Gender Gap in Education are zero then the Inequality of Education in the Riau Islands province will decrease by 0.217286 .

12. Interpretation of DKI Jakarta Province

If the Inequality of Income, Poverty and Gender Gap in Education are zero then the Inequality of Education in DKI Jakarta province will decrease by 0.662054 .

13. Interpretation of West Java Province

If the Inequality of Income, Poverty and Gender Gap in Education are zero then the Inequality of Education in the province of West Java will decrease by 0.391974 .

14. Interpretation of Central Java Province

If the Income, Poverty and Gender Gap in Education Gap is zero then the Education Inequality in Central Java province will decrease by 0.406277 .

15. Interpretation of DI Yogyakarta Province

If the Inequality of Income, Poverty and Gender Gap in Education are zero then the Inequality of Education in the province of Yogyakarta will be reduced by 0.31057 .

16. Interpretation of East Java Province

If the Inequality of Income, Poverty and Gender Gap in Education are zero then the Inequality of Education in East Java province will be reduced by 0.399458 .

17. Interpretation of Banten Province

If the Income, Poverty and Gender Gap in Education Gap is zero then the Education Inequality in Banten province will decrease by 0.320008 .

18. Interpretation of the Province of Bali

If the Inequality of Income, Poverty and Gender Gap in Education are zero then the Inequality of Education in the province of Bali will decrease by 0.351405 .

19. Interpretation of the Province of West Nusa Tenggara

If the Income, Poverty and Gender Gap in Education Gap is zero then the Education Inequality in West Nusa Tenggara Province will decrease by 0.445226 .

20. Interpretation of the Province of East Nusa Tenggara 
If the income inequality, poverty and gender gap in education are zero, the education inequality in the province of East Nusa Tenggara will decrease by 0.498652 .

21. Interpretation of the Province of West Kalimantan

If the Income, Poverty and Gender Gap in Education Gap is zero then the Education Inequality in West Kalimantan province will decrease by 0.376616 .

22. Interpretation of the Province of Central Kalimantan

If the Income, Poverty and Gender Gap in Education Gap is zero then the Education Inequality in Central Kalimantan province will decrease by 0.351936 .

23. Interpretation of the Province of South Kalimantan

If the Income, Poverty and Gender Gap in Education Gap is zero then the Education Inequality in South Kalimantan province will decrease by 0.25355.

24. Interpretation of East Kalimantan Province

If the Income, Poverty and Gender Gap in Education Gap is zero then the Education Inequality in East Kalimantan province will decrease by 0.525818 .

25. Interpretation of North Kalimantan Province

If the Income, Poverty and Gender Gap in Education Gap is zero then the Education Inequality in North Kalimantan province will decrease by 0.331555 .

26. Interpretation of North Sulawesi Province

If the Income, Poverty and Gender Gap in Education Gap is zero then the Education Inequality in North Sulawesi province will decrease by 0.29555 .

27. Interpretation of Central Sulawesi Province

If the Inequality of Income, Poverty and Gender Gap in Education are zero then the Inequality of Education in the province of Central Sulawesi will decrease by 0.395732 .

28. Interpretation of South Sulawesi Province

If the income inequality, poverty and gender gap in education are zero, the education inequality in the province of South Sulawesi will decrease by 0, 344377.

29. Interpretation of Southeast Sulawesi Province

If the Income, Poverty and Gender Gap in Education Gap is zero then the Education Inequality in Southeast Sulawesi province will decrease by 0.387142 .

30. Interpretation of Gorontalo Province

If the Income, Poverty and Gender Gap in Education Gap is zero then the Education Inequality in Gorontalo province will decrease by 0.438861 .

31. Interpretation of West Sulawesi Province

If the Inequality of Income, Poverty and Gender Gap in Education are zero then the Inequality of Education in the province of West Sulawesi will decrease by 0.350382 .

32. Interpretation of Maluku Province

If the Income, Poverty and Gender Gap in Education Gap is zero then the Education Inequality in Maluku province will decrease by 0.3484753 .

33. Interpretation of North Maluku Province

If the Income, Poverty and Gender Gap in Education Gap is zero then the Education Inequality in North Maluku province will decrease by 0.319865 .

34. Interpretation of the Province of West Papua

If the Income, Poverty and Gender Gap in Education Gap is zero then the Education Inequality in West Papua province will decrease by 0.423417 .

35. Interpretation of Papua Province

If the Inequality of Income, Poverty and Gender Gap in Education are zero then the Inequality of Education in Papua province will decrease by 0.423384 . 


\subsection{Hypothesis Test Results}

\section{a. Test $\mathbf{t}$ - Statistics}

T-statistic test is used to determine the effect of each independent variable on the dependent variable (Ghozali, 2013). T test is used to determine the significance of the effect of partially independent variables on the dependent variable by assuming other variables are constant. Probability value of research variables with a significance level of $\alpha$ of $0.05(5 \%)$. If the probability of tcount $>0.05$ then $\mathrm{H} 0$ is accepted and $\mathrm{H} 1$ is rejected, conversely if the probability of tcount $<0.05$ then $\mathrm{H} 0$ is rejected and $\mathrm{H} 1$ is accepted (Ghozali, 2013).

Table 3. T-Statistics Test Results

\begin{tabular}{|c|r|r|r|r|}
\hline Variable & Coefficient & Std. Error & t-Statistic & Prob. \\
\hline C & -0.381306 & 0.084794 & -4.496859 & 0.0000 \\
\hline X1 & 1.247059 & 0.530605 & 2.350258 & 0.0218 \\
\hline X2 & 1.157811 & 0.218354 & 5.302460 & 0.0000 \\
\hline X3 & 0.742234 & 0.133961 & 5.540671 & 0.0000 \\
\hline
\end{tabular}

Source: Data processed with Eviews 9

1. Inequality of Income (X1)

Based on table 4.13 shows that the income inequality variable has a t-statistic of 2.350258 and a probability value of 0.0218 which is smaller than the level of confidence $\alpha=5 \%(0.0218<0.05)$. In addition, the coefficient value of income inequality variable is 1.247059 , a positive sign indicates a positive influence between income inequality variables on educational inequality. Then it can be concluded that the income inequality variable has a positive and significant effect on the education inequality of the Provinces in Indonesia.

2. Poverty (X2)

Based on table 4.13 shows that the poverty variable has a t-statistic of 5.302460 and a probability value of 0.0000 which is smaller than the level of confidence $\alpha=5 \%(0.0218$ $<0.05)$. In addition, the coefficient value of the poverty variable is 1.157811 , a positive sign indicates a positive influence between the poverty variable on educational inequality. Then it can be concluded that the poverty variable has a positive and significant effect on the imbalance of education in the provinces in Indonesia.

3. Gender Gap Education (X3)

Based on table 4.13 shows that the education gender gap variable has a t-statistic of 5.540671 and a probability value of 0.0000 which is smaller than the level of confidence $\alpha=5 \%(0.0218<0.05)$. In addition, the coefficient value of the education gender gap variable is 0.742234 , a positive sign indicates a positive influence between the education gender gap variable on educational inequality. Then it can be concluded that the education gender gap variable has a positive and significant effect on the education disparity of the Provinces in Indonesia.

\section{b. F-Statistics Test}

F-statistical test is used to determine the effect of independent variables on the dependent variable simultaneously (Ghozali, 2013). Hypothesis testing is done by comparing the value of Prob (F-Statistics) with a significance level of $\alpha$ of 0.05 (5\%). If the probability of Fcount $>0.05$ then $\mathrm{H} 0$ is accepted and $\mathrm{H} 1$ is rejected, conversely if the probability of tcount $<0.05$ then $\mathrm{H} 0$ is rejected and $\mathrm{H} 1$ is accepted (Ghozali, 2013). 
Table 4. F Statistic Testing Results

\begin{tabular}{|c|c|c|}
\hline F-Statistic & Prob & Interpreted \\
\hline 39.60269 & 0.000000 & Significant $\alpha=5 \%$ \\
\hline
\end{tabular}

Source: Data processed with Eviews 9

Based on table 4.13 above, the results of data processing obtained the calculated $\mathrm{F}$ value of 39.60269 with a probability of 0.000000 smaller than $\alpha=5 \%$ thus $\mathrm{H} 0$ is rejected. So the Income Inequality (IW), Poverty, Gender Gap Education variables have a significant effect together on Education Inequality in Indonesia.

\section{c. Determination Coefficient Test (R2)}

According to Gujarati and Porter (2004) the magnitude of R2 is known as the coefficient of determination which is the most commonly used measure to measure the goodness of fit of a regression line. These values see how much influence the independent variable together can provide an explanation of the dependent variable, where the value of the coefficient of determination (R2) is between 0 to $1(0 \leq R 2 \leq 1)$. This means that if $R 2$ $=0$, it shows that there is no influence between the independent variables on the dependent variable. The smaller R2 approaches 0 , it can be said the smaller the influence of the independent variable on the dependent variable. Conversely, if R2 gets closer to 1, it shows the stronger influence of independent variables on the dependent variables.

Table 5. Determination Coefficient Test Results (R2)

\begin{tabular}{|c|c|}
\hline $\mathrm{R}-$ Squared & 0.956396 \\
\hline
\end{tabular}

Source: Data processed with Eviews 9

Based on the table above, the results of data processing obtained value

R-squared is 0.956396 , which means that the Income Inequality (IW), Poverty and Gender Gap Education variables contribute to Education Inequality in Indonesia by $95.64 \%$ and the remaining $4.36 \%$ is influenced by variables outside the model

Based on the results of the analysis that has been conducted regarding the factors that influence educational inequality in Indonesia, the following conclusions are obtained:

1. Educational inequality in Indonesia is included in the category of moderate inequality with an average of 0.3243 . In addition, the level of education completed by the population in Indonesia is also still low with an average of 8,073 years, which means that the average population in Indonesia is still incomplete in carrying out 9-year compulsory education.

2. The variables used to explain Education Inequality in Indonesia are Inequality Income, Poverty and Gender Education Gap.

3. Variable Income Inequality, Poverty and Gender Gap Education has a positive and significant relationship to Education Inequality with a level $\alpha=5 \%$ for the three variables. This is consistent with the initial hypothesis which states that the level of income inequality, poverty and gender gap education is positively related to education inequality.

4. From the coefficient of determination (R2) on the estimation results of the model (Data Panel) of the Income, Poverty and Gender Gap Education variable, is able to explain the Education Inequality variable in Indonesia of 0.956396 or $95.64 \%$. Whereas the remaining 0.0436 or $4.36 \%$ Education Inequality in Indonesia is influenced by other variables not examined in this research model. 


\section{Conclusion}

Presenting digital teaching materials is a link between mutualism between efforts to instill ecological intelligence to children, with a tangible manifestation of preserving nature by reducing paper consumption. The Industrial Revolution Era 4.0 indeed demanded the ability of humans to live in the digital realm. Can be witnessed with the naked eye how humans can not escape from the internet and digital products. Facebook, Twitter, WhatsApp and Instagram become compulsory consumption for modern society. Information becomes easy to obtain and disseminate. In the realm of books, many books have been digitized and distributed via the internet so that they can be accessed for free. Many writers also choose to publish their books in digital form as work efficiency.

The preparation of digital teaching materials does not merely digitize printed books of teaching materials, or in other words only changes from printed versions to digital versions. More than that, the preparation of digital teaching materials must present an interactive feel in learning. That way, the independence function of teaching materials as self-explanatory power and self-contained can be fulfilled. Presenting digital teaching materials is not an attempt to undermine the world of books, although signals in that direction continue to be revealed. Digital teaching materials are efforts to expand the range of learning to be more accessible for teachers and students in need.

The revolution indeed requires the achievement of radical change. Change from centralized to peripheral. Changes from printed to digital. The change from Java-centric to ecocentric indeed has a broad impact on human life, especially the world of books. Avoiding revolution is impossible, while turning challenges into opportunities is the most realistic thing to do.

\section{References}

Ariutama, I.G.A., and Syahrul. (2014). Analisis Tingkat Pendidikan, Tingkat Kesehatan dan Ketimpangan Pendapatan di Indonesia. Balai Diklat Keuangan Balikpapan.

Badan Pusat Statistik (BPS). (2019). Sumatera Utara dalam Angka tahun 2019. Sumatera Utara.

Bustomi M.J. (2012). Ketimpangan pendidikan antar kabupaten/kota dan implikasinya di Provinsi Jawa Tengah. Jurusan Ekonomi Pembangunan, Fakultas Ekonomi, Universitas Negeri Semarang, Indonesia.

Chernichovsky, D. (1985). Socioeconomic and demographic aspects of school enrollment and attendance in rural Bostwana. Economic Developmnet and cultural Change, 33 (2): $319-332$.

Digdowiseiso K. (2010). Measuring gini coefficient of education: the Indonesian cases. MPRA Paper No. 19865. University Library of Munich. Germany.

Ghozali, I. (2013). Aplikasi Analisis Multivariat dengan Program IBM SPSS. Edisi 7. Semarang: Penerbit Universitas Diponogoro.

Grimm, M. (2011). Does household income matter for children's schooling? Evidence for rural Sub-Saharan Africa. Economics of Education Review, 30 :740 -754.

Gujarati D.N. (2004). Basic Econometrics 4th Edition. New York: McGraw Hill.

Hamzah, et al. (2017). Pengaruh Pengeluaran Pemerintah Bidang Pendidikan, Gender Gap dan Pendapatan Perkapita terhadap Ketimpangan Pendidikan dan Ketimpangan Pendapatan Kabupaten/Kota di Provinsi Kalimantan Barat. Jurnal Ekonomi Bisnis dan Kewirausahaan, 6 (2): 77-96. 
Kaplan, G.A., et.al. (1996). Inequality in Income and Mortality in The United States: Analysis of Mortality and Potential Parthways. Bmj, 312 (7037): 999-1993.

Kuncoro, M. (2006). Ekonomi Pembangunan. Salemba Empat: Jakarta.

Nugroho, R. (2011). Gender dan Strategi Pengarus-Utamaannya di Indonesia. Yogyakarta: Pustaka Pelajar.

Psachoropoulos, G. and Arriagada, M. (2016). The Determinants of Early Age Human Capital Formation: Evidence From Brazil. Chicago Press Terms and Conditions.

Senadza, B. (2012). Education Inequality in Ghana: Gender and Spatial Dimensions. Jorunal of Economic Studies, 39 (6): 724-739.

Sen, A. K. (2000). Development as Freedom. New York:Anchor Books.

Shapiro, D., \& Tambashe, B. O. (1999). Gender, poverty, and school enrollment in Kinshasa, Congo. In Union for African Popul ation Studies, Third African Population Conference: The African Population in the 21st Century, 3: 587-615.

Shapiro, D., \& Tambashe, B. O. (2001). Gender, poverty, family structure, and investments in children's education in Kinshasa, Congo. Economics of Education Review, 20 (4), 359-375.

Sholikhah., S. (2014). Analisis Faktor yang Memengaruhi Ketimpangan Pendidikan. Jurnal Ilmu Pendidikan, 20 (2): 176-182.

Sugiharto. (2020).Geographical students' learning outcomes on basic political science by using cooperative learning model with Group Investigation (GI) type in State University of Medan, Indonesia, Journal of Human Behavior in the Social Environment, 30:4, P. 447-456.

Suryadarma, et al. (2006). Causes of low secondary school enrollment in Indonesia. SMERU Working Paper: Jakarta.

Suryadi, A and Idris, E. (2010). Kesetaraan Gender dalam Bidang Pendidikan. Bandung: PT. Genesindo.

Sylwester, K. (2000). Income Inequality Education Expenditures and Growth. Journal of Development Economics, 63 (2): 379-398.

Tesfeye K. (2002). The economics of education: conceptual framework. Journal of African Economies, 26: 357-374.

Todaro M.P. Smith SC. (2011). Pembangunan Ekonomi. Ed ke-11. Jakarta: Erlangga.

Thomas V. et.al. (2001). Measuring education inequality : Gini coefficients of Education. Policy Research Working Paper. World Bank Institute. No. 2525.

Yagami, F. (2013). Kesenjangan antara Harapan dengan Kenyataan. http://www.slideshare.net/fitrayagami/kesenjangan-antara-harapan-dengan-kenyataan. 